\title{
PENILAIAN AUTENTIK MATA PELAJARAN PENDIDIKAN AGAMA ISLAM DAN BUDI PEKERTI DI SMP NEGERI 4 PARIAMAN
}

\author{
Novialdi Putra \\ Pegawai STAI Solok, Kota Solok, Sumatera Barat \\ E-mail: novia ld iputra hasyam@gma il.com
}

\begin{abstract}
A qualitative study was conducted at investigating the implementation of authentic assessment in curriculum 2013 on Islamic education and attitude of SMP Negeri 4 Pariaman and the factors supporting and inhibiting the authentic assessment. This study applied observation, interview, and documentation. The results showed that the implementation of authentic assessment was run well. The assessment upgraded the students' interest and students' creative. The assessment also increased students' motivation on activities were done in school environment. The factor supported the implementation of authentic assessment was workshop and infrastucture while the factor inhibitted the implementation was too many students in the class.
\end{abstract}

Keywords: Authentic Assessment, Curriculum 2013, Islamic Education, Attitude, SMP.

\section{PENDAHULUAN}

Pertumbuhan dan perkembangan pendidikan di Indonesia sangat dipengaruhi oleh kebijakan-kebijakan pemerintah yang terkadang tidak sesuai dengan harapan yang diinginkan oleh masyarakat. Maka pendidikan di Indonesia sering kali berhadapan dengan berbagai problematika yang tidak ringan. Diketahui bahwa sebagai sebuah sistem, pendidikan mengandung berbagai komponen yang antara satu dan lainnya saling berkaitan (Nata, 2012).

Komponen pendidikan tersebut meliputi visi, misi, landasan, tujuan, kurikulum, kompetensi dan profesionalisme guru, pola hubungan pendidik dan peserta didik, metodologi pembelajaran, sarana prasarana, pengelolaan, evaluasi, pembiayaan, dan lain sebagainya. Pendidikan itu sendiri dalam ruang lingkup mikro berintikan interaksi antara pendidik dan peserta didik dalam upaya membantu peserta didik menguasai tujuan-tujuan pendidikan. Interaksi pendidikan dapat berlangsung dalam lingkungan keluarga, sekolah, ataupun masyarakat (Sukmadinata, 2011).

Pendidikan dalam lingkungan sekolah lebih bersifat formal, serta memiliki beberapa kelebihan dibandingkan dengan pendidikan informal dalam lingkungan keluarga. Pertama, memiliki lingkup isi pendidikan 
yang lebih luas, bukan hanya yang berkenaan dengan pembinaan segi-segi moral, tetapi ilmu pengetahuan dan keterampilan. Kedua, pendidikan disekolah telah dirancang secara berencana, sistematis dan memiliki kurikulum. Perubahan kurikulum diperlukan karena adanya perubahan zaman, sehingga kebutuhan dalam bidang pendidikan pun ikut berubah, baik dari sisi pengetahuan, keterampilan, maupun sikap yang harus dimiliki generasi muda bangsa. Apalagi Indonesia memiliki bonus demografi dalam jumlah usia penduduk yang produktif dalam kurun waktu 2010-2040.

Kurikulum mempunyai kedudukan sentral dalam seluruh proses pendidikan serta mengarahkan segala bentuk aktivitas pendidikan demi tercapainya tujuan-tujuan pendidikan. Kurikulum berkembang sejalan dengan perkembangan teori dan praktik pendidikan dan kurikulum merupakan proses dinamik sehingga dapat merespon terhadap tuntutan perubahan struktural pemerintahan, perkembangan ilmu dan teknologi maupun globalisasi (Hamalik, 2010). Kurikulum berubah karena mengikuti perubahan zaman, bukan karena kurikulum yang terdahulu jelek atau salah. Sudah benar itu zamannya, tapi zaman berubah karena kemajuan ilmu pengetahuan dan teknologi. Serta kurikulum dirancang sesuai kebutuhan masyarakat dan pasar dalam negeri (Forum Mangunwijaya VII, 2013).

Upaya penyempurnaan kurikulum demi mewujudkan sistem pendidikan nasional yang kompetitif dan selalu relevan dengan perkembangan zaman yang senantiasa menjadi tuntutan. Hal ini sejalan dengan undang-undang Nomor 20 tahun 2003 tentang Sisdiknas pasal 35 dan 36 yang menekankan perlunya peningkatan standar nasional pendidikan sebagai acuan kurikulum secara berencana dan berkala dalam rangka mewujudkan tujuan pendidikan nasional (Undang-Undang No. 20 Tahun 2003).

Di Indonesia kurikulum mengalami beberapa perbaikan di antaranya kurikulum 1994 yang pada gilirannya diganti dengan KBK 2004. Penerapan kurikulum berbasis kompetensipun di sekolah tidak bertahan lama, karena dua tahun kemudian pemerintah meluncurkan Kurikulum Tingkat Satuan Pendidikan (KTSP) di tahun 2006. Sebagai penyempurna dari kurikulum sebelumnya, maka kementrian pendidikan dan kebudayaan meluncurkan kurikulum 2013 (Mulyasa, 2013). Pengembangan Kurikulum 2013 dilakukan dalam empat tahap. Pertama, penyusunan kurikulum di lingkungan internal Kemendikbud dengan melibatkan sejumlah pakar dari berbagai disiplin ilmu dan praktisi pendidikan. Kedua, pemaparan desain Kurikulum 2013 di depan Wakil Presiden selaku Ketua Komite Pendidikan yang telah dilaksanakan pada 13 November 2012 serta di depan Komisi X DPR RI pada 22 November 2012. Ketiga, pelaksanaan uji publik guna mendapatkan tanggapan dari berbagai elemen masyarakat. Salah satu cara yang ditempuh selain melalui saluran daring 
(online), juga melalui media massa cetak. Tahap keempat, dilakukan penyempurnaan untuk selanjutnya ditetapkan menjadi Kurikulum 2013.

Kurikulum 2013 ini, dirancang sebagai upaya mempersiapkan generasi indonesia 2045 (100 tahun indonesia merdeka), sekaligus memanfaatkan momentum populasi usia produktif yang jumlahnya sangat melimpah agar menjadi bonus demografi dan tidak menjadi bencana demografi (Muzamiroh, 2013). Sebagaimana yang telah dicanangkan oleh Menteri Pendidikan dan Kebudayaan, bahwasanya kurikulum 2013 akan diterapkan diberbagai jenjang pendidikan, mulai pada pendidikan tingkat dasar sampai tingkat menengah atas. Sebagai langkah awal, kurikulum 2013 diterapkan pada kelas IV, V, VI Sekolah Dasar, kelas VII Sekolah Menengah Pertama, dan kelas X Sekolah Menengah Atas.

Implementasi kurikulum 2013 merupakan aktualisasi kurikulum dalam pembelajaran dan pembentukan kompetensi serta karakter peserta didik. Hal tersebut menuntut keaktifan guru secara profesional dalam merancang pembelajaran efektif dan bermakna (menyenangkan), mengorganisasikan pembelajaran, memilih pendekatan pembelajaran yang tepat, menentukan prosedur pembelajaran dan pembentukan kompetensi secara efektif, serta menetapkan kriteria keberhasilan (Mulyasa, 2013). Kurikulum 2013 dikembangkan untuk meningkatkan capaian pendidikan dengan 2 (dua) strategi utama yaitu peningkatan efektifitas pembelajaran pada satuan pendidikan dan penambahan waktu pembelajaran disekolah (Poerwati dan Amri, 2013).

Menurut Poerwati dan Amri (2013), Efektifitas pembelajaran dicapai melalui 3 tahapan yaitu, pertama, efektifitas interaksi, efektifitas ini akan tercipta dengan adanya harmonisasi iklim akademik dan budaya sekolah, kedua, efektifitas pemahaman, hal ini menjadi bagian penting dalam pencapaian efektifitas pembelajaran, ketiga, efektifitas penyerapan, dapat tercipta mana kala adanya kesinambungan pembelajaran secara horizontal dan vertikal. Dalam implementasinya kurikulum 2013 ada beberapa perubahan di mata pelajaran dari kurikulum KTSP, seperti mata pelajaran Pendidikan Agama Islam berubah menjadi Pendidikan Agama dan Budi Pekerti. Inilah perubahan yang paling mencolok dalam kurikulum 2013, dari pada mata pelajaran yang lainnya.

Sekolah merupakan suatu lembaga formal yang mempersiapkan peserta didik dan sumber daya manusia yang berkualitas. Dalam hal ini mata pelajaran pendidikan agama dan budi pekerti yang sangat berperan penting dalam mengembangkan akhlak, sikap atau moral para peserta didik. Bukan hanya peserta didik yang pandai dalam hal kognitif, tapi juga pandai dalam hal afektif. Dengan demikian akan terjadinya keseimbangan antara dua kecerdasan 
tersebut, dan menghasilkan peserta didik yang secara intelektual berkualitas serta secara akhlak dan perilaku sehari-hari yang berkuantitas sesuai ajaran Islam (Suharto, 2011).

Secara historis pertumbuhan dan perkembangan pendidikan Islam di indonesia sangat terkait erat dengan kegiatan dakwah islamiyah. Pendidikan Islam berperan sebagai mediator dalam membina dan mendidik para peserta didik sesuai dengan ajaran Islam yang berlandasan AlQur'an dan As-Sunnah. Melalui pendidikan inilah, peserta didik dapat memahami, dan mengamalkan ajaran Islam sebagaimana mestinya (Nata, 2012). Sehubungan dengan itu, maka tingkat kedalaman, penghayatan, dan pengalaman peserta didik terhadap ajaran Islam amat tergantung pada tingkat kualitas pendidikan Islam yang diterimanya, serta tingkat kualitas dan kuantitas para guru yang sebagai pendidik dan sebagai uswatun hasanah bagi peserta didik.

Secara kuantitatif, jam pelajaran pendidikan agama dan budi pekerti hanya sedikit bila dibandingkan dengan mata pelajaran lain. Dalam tingkat sekolah menengah pertama saja jam pelajaran pendidikan agama dan budi pekerti hanya 3 jam perminggu. Sedangkan secara kualitatif, pendidikan agama dan budi pekerti merupakan inti dari kurikulum pendidikan sekolah. Dengan konsep kurikulum berbasis kompetensi, tak tepat jika ada yang menyampaikan bahwa pemerintah salah sasaran saat merencanakan perubahan kurikulum, karena yang perlu diperbaiki sebenarnya metodologi pembelajaran bukan kurikulum.

Seperti yang diutarakan oleh Mohammad Abduhzen, Hal ini menunjukkan belum dipahaminya secara utuh bahwa kurikulum berbasis kompetensi termasuk mencakup metodologi pembelajaran (Hamalik, 2010). Tanpa metodologi pembelajaran yang sesuai, tak akan terbentuk kompetensi yang diharapkan. Sebagai contoh, dalam Kurikulum 2013, kompetensi lulusan dalam ranah keterampilan untuk SD dirumuskan sebagai "memiliki (melalui mengamati, menanya, mencoba, mengolah, menyaji, menalar, mencipta) kemampuan pikir dan tindak yang produktif dan kreatif, dalam ranah konkret dan abstrak, sesuai dengan yang ditugaskan kepadanya."

Pemikiran pengembangan Kurikulum 2013 seperti diuraikan di atas dikembangkan atas dasar taksonomi-taksonomi yang diterima secara luas, kajian KBK 2004 dan KTSP 2006, dan tantangan Abad 21 serta penyiapan Generasi 2045. Dengan demikian, tidaklah tepat apa yang disampaikan Elin Driana, yang mengharapkan sebelum Kurikulum 2013 disahkan, baiknya dilakukan evaluasi terhadap kurikulum sebelumnya (Poerwati dan Amri, 2013). Belum lagi rumusan kompetensi yang belum sesuai dengan tuntutan UU dan praktik terbaik di dunia, ketidaksesuaian materi mata pelajaran dan tumpang tindih 
yang tidak diperlukan pada beberapa materi mata pelajaran, kecepatan pembelajaran yang tidak selaras antara mata pelajaran, dangkalnya materi, proses, dan penilaian pembelajaran, sehingga peserta didik kurang dilatih bernalar dan berfikir.

Inti dari Kurikulum 2013, adalah ada pada upaya penyederhanaan, dan tematikintegratif. Kurikulum 2013 disiapkan untuk mencetak generasi yang siap di dalam menghadapi masa depan. Karena itu kurikulum disusun untuk mengantisipasi perkembangan masa depan. Titik beratnya, bertujuan untuk mendorong peserta didik, mampu lebih baik dalam melakukan observasi, bertanya, bernalar, dan mengkomunikasikan (mempresentasikan), apa yang mereka peroleh atau mereka ketahui setelah menerima materi pembelajaran. Adapun obyek yang menjadi pembelajaran dalam penataan dan penyempurnaan kurikulum 2013 menekankan pada fenomena alam, sosial, seni, dan budaya. Melalui pendekatan itu diharapkan peserta didik kita memiliki kompetensi sikap, keterampilan, dan pengetahuan jauh lebih baik. Mereka akan lebih kreatif, inovatif, dan lebih produktif, sehingga nantinya mereka bisa sukses dalam menghadapi berbagai persoalan dan tantangan di zamannya, memasuki masa depan yang lebih baik.

Pelaksanaan penyusunan kurikulum 2013 adalah bagian dari melanjutkan pengembangan Kurikulum Berbasis Kompetensi (KBK) yang telah dirintis pada tahun 2004 dengan mencakup kompetensi sikap, pengetahuan, dan keterampilan secara terpadu, sebagaimana amanat UU 20 tahun 2003 tentang Sistem Pendidikan Nasional pada penjelasan pasal 35, di mana kompetensi lulusan merupakan kualifikasi kemampuan lulusan yang mencakup sikap, pengetahuan, dan keterampilan sesuai dengan standar nasional yang telah disepakati. Paparan ini merupakan bagian dari uji publik Kurikulum 2013, yang diharapkan dapat menjaring pendapat dan masukan dari masyarakat.

Dengan demikian seluruh elemen yang terlibat dalam hal ini, seperti; kepala sekolah, guru, orang tua sangat berperan penting dalam membina dan membimbing peserta didik agar akhlak dan perilakunya tidak merosot karena dipengaruhi oleh perkembangan zaman yang semakin modern dan praktis. Dengan diterapkanya kurikulum 2013 ini, agar supaya faktor-faktor yang merusak akhlak dan perilaku peserta didik dari intern maupun ekstern dapat diminimalisir dengan adanya mata pelajaran pendidikan agama dan budi pekerti. Keberhasilan kurikulum 2013 ini bukan hanya tanggung jawab sekolah saja tetapi merupakan tanggung jawab dari semua pihak; orang tua, pemerintah, dan masyarakat (Muzamiroh, 2013). Menurut Mulyasa (2013), ada beberapa indikator yang dapat dilihat dalam keberhasilan kurikulum 2013, antara lain 1) adanya lulusan yang berakhlakul karimah dan memiliki moral yang baik, 2) adanya lulusan yang berkualitas, produktif, kreatif, dan mandiri, 3) peningkatan mutu pembelajaran 
serta terwujudnya pembelajaran aktif, kreatif, efektif, menyenangkan dan peningkatan efisiensi dan efektivitas pengelolaan dan pendayagunaan sumber belajar, 4) peningkatan perhatian serta partisipasi orang tua dan masyarakat.

Indikator-indikator diatas bisa dicapai bila mana para pendidik menilai peserta didik menggunakan penilaian deskriptif bukan penilaian dengan angka-angka. Karena dalam penilaian deskriptif, hasil proses pembelajaran lebih detail dan mengetahui seberapa mampu peserta didik mencapai tujuan pembelajaran yang ingin dicapai. Dalam implementasi kurikulum 2013 menggunakan evaluasi pembelajaran dengan penilaian autentik. Penilaian autentik (authentic assessment) adalah pengukuran yang bermakna secara signifikan atas hasil belajar peserta didik untuk ranah sikap, keterampilan, dan pengetahuan.

Penilaian autentik memiliki relevansi kuat terhadap pendekatan ilmiah dalam pembelajaran sesuai dengan tuntutan Kurikulum 2013. Penilaian tersebut mampu menggambarkan peningkatan hasil belajar peserta didik, baik dalam rangka mengobservasi, menalar, mencoba, membangun jejaring, dan lain-lain. Dalam penilaian autentik cenderung fokus pada tugas-tugas kompleks atau kontekstual, memungkinkan peserta didik untuk menunjukkan kompetensi mereka dalam pengaturan yang lebih autentik. Serta sangat relevan dengan pendekatan tematik terpadu dalam pembejajaran, khususnya jenjang sekolah dasar dan menengah pertama atau untuk mata pelajaran yang sesuai.

Pada penilaian autentik pendidik menerapkan kriteria yang berkaitan dengan konstruksi pengetahuan, kajian keilmuan, dan pengalaman yang diperoleh dari luar sekolah. Penilaian ini mencoba menggabungkan kegiatan pendidik mengajar, kegiatan peserta didik belajar, motivasi dan keterlibatan peserta didik, serta keterampilan belajar. Karena penilaian itu merupakan bagian dari proses pembelajaran, pendidik dan peserta didik berbagi pemahaman tentang kriteria kinerja.

Atas dasar inilah penulis ingin menganalisis serta membuktikan dilapangan bagaimana implementasi penilaian autentik kurikulum 2013 di SMP Negeri 4 Pariaman, lebih khususnya pada mata pelajaran pendidikan agama Islam dan budi pekerti. Adapun yang mendorong penulis untuk melakukan penelitian di SMP Negeri 4 Pariaman adalah karena sekolah ini merupakan salah satu sekolah negeri yang dipandang favorit oleh kebanyakan masyarakat dan juga sebagai lembaga percontohan dalam implementasi kurikulum 2013. Dari uraian di atas, maka kajian ini fokusnya adalah penilaian autentik mata pelajaran pendidikan agama islam dan budi pekerti di SMP Negeri 4 Pariaman".

\section{KURIKULUM 2013}

Dalam mengartikan kurikulum, setiap orang, kelompok masyarakat, atau ahli 
pendidikan dapat mempunyai penafsiran yang berbeda tentang pengertian kurikulum. Berdasarkan studi yang telah dilakukan oleh banyak ahli, dapat disimpulkan bahwa pengertian kurikulum dapat ditinjau dari dua sisi yang berbeda, yakni menurut pandangan lama dan pandangan baru (Hamalik, 2010).

Menurut pandangan lama, atau sering juga disebut pandangan tradisional, merumuskan bahwa kurikulum adalah sejumlah mata pelajaran yang harus ditempuh peserta didik untuk memperoleh ijazah, dan mempunyai sistem penyampaian yang digunakan oleh guru adalah sistem penuangan (Forum Mangunwijaya, 2013). Akibatnya, dalam proses belajar mengajar gurulah yang lebih banyak bersikap aktif, sedangkan peserta didik hanya bersifat pasif belaka serta adanya aspek keharusan bagi setiap peserta didik untuk mempelajari mata pelajaran yang sama. Akibatnya, faktor minat dan kebutuhan peserta didik tidak dipertimbangkan dalam penyusunan kurikulum.

Sedangkan menurut pandangan baru atau disebut juga pendangan modern, seperti yang dikemukakan oleh Romine (Mulyasa, 2013), bahwasanya dapat dirumuskan sebagai berikut "curriculum is interpreted to mean all of the organized courses, activities, and experiences which pupils have under direction of the school, whether in the clasroom or not". Implikasi perumusan di atas bahwasanya kurikulum bersifat luas, karena kurikulum bukan hanya terdiri atas mata pelajaran (courses), tetapi meliputi semua kegiatan dan pengalaman yang menjadi tanggung jawab sekolah. Dan mempunyai sistem penyampaian yang dipergunakan oleh guru disesuaikan dengan kegiatan atau pengalaman yang akan disampaikan. Oleh karena itu, guru harus mengadakan berbagai kegiatan belajar mengajar yang bervariasi, sesuai dengan kondisi peserta didik (Mulyasa, 2013). Serta pelaksanaan kurikulum tidak hanya dibatasi pada keempat dinding kelas saja, melainkan dilaksanakan baik didalam maupun diluar kelas, sesuai dengan tujuan pembelajaran yang hendak dicapai.

Kurikulum 2013 merupakan tindak lanjut dari Kurikulum Berbasis Kompetensi (KBK) yang pernah diujicobakan pada tahun 2004. KBK atau (Competency Based Curriculum) dijadikan acuan dan pedoman bagi pelanksanaan pendidikan dalam mengembangkan kompetensi sikap, pengetahuan, dan keterampilan secara terpadu, sebagaimana amanat UU 20 tahun 2003 tentang Sistem Pendidikan Nasional pada penjelasan pasal 35, di mana kompetensi lulusan merupakan kualifikasi kemampuan lulusan yang mencakup sikap, pengetahuan, dan keterampilan sesuai dengan standar nasional yang telah disepakati (Muzamiroh, 2013). Paparan ini merupakan bagian dari uji publik Kurikulum 2013, yang diharapkan dapat menjaring pendapat dan masukan dari masyarakat.

Kurikulum 2013 yang berbasis karakter dan kompetensi lahir sebagai jawaban 
terhadap kurikulum KTSP yang menuai berbagai kritikan, serta sesuai dengan perkembangan kebutuhan dan dunia kerja. Kurikulum 2013 merupakan salah satu upaya pemerintah untuk mencapai keunggulan masyarakat bangsa dalam penguasaan ilmu dan teknologi seperti yang digariskan dalam haluan Negara (Forum Mangunwijaya, 2013). Serta menghasilkan insan Indonesia yang produktif, kreatif, inovatif, afektif, melalui penguatan sikap, keterampilan, dan pengetahuan yang terintegrasi.

Kurikulum terintegrasi merupakan kurikulum yang memungkinkan peserta didik baik secara individual maupun secara klasikal aktif menggali dan menemukan konsep dan prinsip-prinsip secara holistik bermakna dan otentik, melalui pertimbangan itu maka berbagai pandangan dan pendapat tentang pembelajaaran terintegrasi, tapi semuanya menekankan pada penyampaian pelajaran yang bermakna dengan melibatkan peserta didik dalam proses pembelajaran (Muzamiroh, 2013).

Kurikulum 2013 berbasis kompetensi memfokuskan pada pemerolehan kompetensi-kompetensi tertentu oleh peserta didik. Oleh karena itu, kurikulum ini mencangkup sejumlah kompetensi, dan seperangkat tujuan pembelajaran yang dinyatakan sedemikian rupa, sehingga pencapaiannya dapat diamati dalam bentuk perilaku atau keterampilan peserta didik sebagai suatu kriteria keberhasilan (Hamalik, 2010). Ada beberapa aspek yang terkandung dalam konsep kompetensi, antara lain sebagai beikut; pengetahuan (knowledge), pemahaman (understanding), kemampuan (skill), nilai (value), sikap (attitude), dan minat (interest).

Paling tidak terdapat dua landasan teoritis yang mendasari Kurikulum 2013 berbasis kompetensi. Pertama, adanya pergeseran dari pembelajaran kelompok kearah pembelajaran individual (Kunandar, 2013). Dalam pembelajaran individual setiap peserta didik dapat belajar sendiri, sesuai dengan cara dan kemampuan masing-masing. Untuk itu, diperlukan pengaturan kelas yang fleksibel, baik sarana maupun waktu, karena dimungkinkan peserta didik belajar dengan kecepatan yang berbeda, penggunaan alat yang berbeda, serta mempelajari bahan ajar yang berbeda pula. Kedua, pengembangan konsep belajar tuntas (mastery learning) atau belajar sebagai penguasaan (learning for mastery) adalah suatu falsafah pembelajaran yang mengatakan bahwa dengan sistem pembelajaran yang tepat, semua peserta didik dapat mempelajari semua bahan yang diberikan dengan hasil yang baik (Kunandar, 2013). Dengan demikian, setiap peserta didik dapat mencapai tujuan pembelajaran secara optimal, jika diberikan waktu yang cukup.

\section{PENILAIAN AUTENTIK DALAM KURIKULUM 2013}

Penilaian dalam kurikulum 2013 mengacu pada Permendikbud Nomor 104 Tahun 2013 tentang Standar Penilaian Pendidikan. Standar 
Penilaian bertujuan untuk menjamin: 1) Perencanaan penilaian peserta didik sesuai dengan kompetensi yang akan dicapai dan berdasarkan prinsip-prinsip penilaian; 2) Pelaksanaan penilaian peserta didik secara profesional, terbuka, edukatif, efektif, efisien, dan sesuai dengan konteks sosial budaya.

Penilaian autentik berbeda dengan penilaian tradisional. Penilaian tradisional peserta didik cenderung memilih respon yang tersedia, sedangkan dalam penilaian autentik peserta didik menampilkan atau mengerjakan suatu tugas atau proyek. Peda penilaian tradisional kemampuan berfikir yang dinilai cenderung pada level memahami dan fokusnya adalah guru. Pada penilaian autentik kemampuan berpikir yang dinilai adalah level konstruksi dan aplikasi serta fokusnya pada peserta didik (Forum Mangunwijaya, 2013). Standar penilaian pendidikan ini disusun sebagai acuan penilaian bagi pendidik, satuan pendidikan, dan pemerintah pada satuan pendidikan untuk jenjang pendidikan dasar dan menengah.

Menurut Permendikbud tersebut standar penilaian pendidikan adalah kriteria mengenai mekanisme, prosedur, dan instrumen penilaian hasil belajar peserta didik. Penilaian pendidikan sebagai proses pengumpulan dan pengolahan informasi untuk mengukur pencapaian hasil belajar peserta didik yang mencakup sebagai berikut: Penilaian autentik, penilaian diri, penilaian berbasis portofolio, ulangan, ulangan harian, ulangan tengah semester, ulangan akhir semester, ujian tingkat kompetensi, ujian mutu tingkat kompetensi, ujian nasional, dan ujian sekolah/madrasah (Hamalik, 2010).

Salah satu penekanan dalam kurikulum 2013 adaah penilaian autentik. Sebenarnya dalam kurikulum sebelumnya, yakni Kurikulum Tingkat Satuan Pendidikan (KTSP) sudah memberi ruang terhadap penilaian autentik, tetapi dalam implementasi di lapangan belum berjalan secara optimal. Melalui kurikulum 2013 adalah penilaian autentik menjadi penekanan yang serius dimana guru dalam melakukan penilaian hasil belajar peserta didik benar- benar memperhatikan penilaian autentik. Sebelum mendefinisikan pengertian penilaian autentik sebaiknya kita mendefinisikan terlebih dahulu mendefnisikan pengertian penilaian. Penilaian adalah proses pengumpulan berbagai data yang bisa memberikan perkembangan belajar siswa.

Dalam penilaian autentik memerhatikan keimbangan antara penilaian kompetensi sikap, pengetahuan dan keterampilan yang disesuaikan dengan perkembangan karakteristik peserta didik sesuai dengan jenjangnya (Mulyasa, 2013). Ciri- ciri penilaian autentik adalah 1) harus mengukur semua aspek pembelajaran, yakni kinerja dan hasil atau produk; 2) dilaksanakan selama dan sesudah proses pembelajaran berlangsung; 3) menggunakan berbagai cara dan sumber; 4) tes hanya salah satu alat pengumpul data penilaian; 5) tugas-tugas yang diberikan kepada peserta didik harus 
mencerminkan bagian-bagian kehidupan pesera didik yang nyata setiap hari, mereka harus dapat menceritakan pengalaman atau kegiatan yang mereka lakukan setiap hari; 6) penilaian harus menekankan kedalaman pengetahuan dan keahlian pesera didik, bukan keluasannya (Poerwati dan Amri, 2013). Sedangkan karakteristik authentic assesment adalah sebagai berikut 1) bisa digunakan untuk formatif maupun sumatif; 2) mengukur keterampilan dan performasi, bukan mengingat fakta; 3) berkesinambungan dan terintegrasi; 4) dapat dignakan sebagai feed back. Artunya, penilaian autentik yang dilakukan oleh guru dapat dijadikan sebagai umpan balik terhadap pencapaian kompetensi peserta didik secara komprehensif (Kunandar, 2013).

Hal-hal yang bisa digunakan sebagai dasar menilai prestasi peserta didik dalam penilaian autentik 1) proyek atau penugaan dan laporannya; 2) hasil tes tulis; 3) portofolio (kumpulan karya peserta didik) selama satu semester atau satu tahun; 4) pekerjaan rumah; 5) kuis; 6) karya peserta didik; 7) presentasi atau penampilan peserta didik; 8) demonstrasi; 9) laporan; 10) jurnal; 11) karya tulis; 12) kelompok diskusi; dan 13) wawancara (Kunandar, 2013). Dari penjelasan tersebut dalam melakukan penilaian autentik ada tiga hal yang harus diperhatikan oleh guru, yaitu 1) autentik dari instrumen yang digunakan; 2) autentik dari aspek yang diukur; 3) autentik dari aspek kondisi peserta didik (Kunandar, 2013).
Autentik dari segi instrumen (tes tertulis, tes lisan, tes proyek, tes kinerja dan sebagainya), dan autentik dari aspek yang dinilai (kompetensi sikap, kompetensi pengetahuan dan kompetensi keterampilan aka dibahas dalam bab tersendiri) (Hamalik, 2010). Sedangkan autentik dilihat dari penilaian input, proses dan output. Dalam penilaian autentik, selain memerhatikan aspek kompetensi sikap (afektif) kompetensi pengetahuan (kognitif) dan kompetensi keterampilan (psikomotorik) serta variasi instrumen atau alat tes yang digunakan juga harus memerhatikan input, proses, dan output peserta didik. Penilaian hasil belajar peserta didik juga harus dilakukan pada awal pembelajaran (penilaian input), selama pembelajaran (penilaian proses), dan setelah pembelajaran (penilaian output) (Mulyasa, 2013). Penilaian input adalah penilaian yang dilakukan sebelum proses belajar mengajar dilakukan. Penilaian input bertujuan untuk mengetahui kemampuan awal peserta didik terhadap materi atau kompetensi yang akan dipelajari. Penilaian input biasanya dilakukan melalui pre tes.

Dengan demikian, kompetensi awal peserta didik dapat dipetakan. Hasil penilaian awal peserta didik dapat dijadikan acuan guru dalam proses belajar mengajar sekaligus dapat dibandingkan dengan penilaian proses dan hasil atau output. Perbandingan hasil penilaian awal (input) dengan penilaian proses dan hasil menunjukkan tingkat keberhasilan pencapaian kompetensi peserta didik dengan KKM sebagai acuan. 
PENDIDIKAN AGAMA ISLAM DAN BUDI PEKERTI

Pada dasarnya mata pelajaran pendidikan Agama Islam dan budi pekerti adalah sama dengan mata pelajaran Agama Islam pada umumnya. Hanya penyebutannya saja yang berbeda karena adanya budi pekerti, perbedaan nama tersebut mengikuti pergantian kurikulum KTSP menjadi Kurikulum 2013. Kandungan dan isi materinya pun sama dengan materi yang ada dalam mata pelajaran pendidikan Agama Islam (Suharto, 2011). Perbedaan hanya terletak pada karakteristik dalam proses pembelajarannya, karena pada kurikulum 2013 isi dari mata pelajaran pendidikan Agama Islam dan budi pekerti harus mencakup 18 karakter, dan lebih mengutamakan peserta didik yang berperan aktif dalam proses pembelajaran.

Pendidikan secara etimologi berasal dari bahasa arab Al-Tarbiyat yang artinya memperbaiki (Ashalaha), menguasai urusan, memelihara, merawat, menunaikan, memperindah, memberi makan, mengasuh, memiliki, mengatur, dan menjaga kelestarian, dan eksistensinya (Suharto, 2011). Tarbiyah merupakan sustu upaya yang mempersiapkan individu untuk kehidupan yang lebih sempurna etika, sistermatis dalam berpikir, memiliki ketajaman intuisi, giat dalam berkreasi, memiliki toleransi kepada orang lai, berkompetensi dalam mengungkap bahasa lisan dan tulis, serta memilki beberapa ketrampilan. Sedangkan istilah yang lain merupakan bagian dari kegiatan tarbiyah. Dengan demikian maka istilah pendidikan Islam disebut tarbiyah Islamiyah.

Sedangkan secara terminology menurut al-Abrasy pendidikan Islam adalah mempersiapkan manusia supaya hidup dengan semurna dan bahagia, mencintai tanah air, tegap jasmaninya, sempurna budi pekertinya (ahklaknya), teratur pikirannya, halus perasaannya, mahir dalam pekerjaannya, manis tutur katanya. Baik dengan lisan ataupun tulisan (Ramayulis, 2004). Sedangkan Marimba (Zuriah, 2008) memberikan pernyataan bahwa pendidikan Islam adalah bimbingan jasmani dan rohani berdasarkan hukum-hukum agama Islam menuju kepada terbentukya kepribadian utama menurut ukuran-ukuran Islam. Dengan memperhatikan kedua definisi di atas akan berarti pendidikan Islam adalah suatu proses edukatif yang mengarah kepada pembentukan akhlak atau kepribadian manusia agar menjadi khalifah yang selalu bertaqwa kepada Allah SWT.

\section{METODE PENELITAN}

Penelitian adalah sebuah cara untuk menemukan jawaban dari rumusan masalah dengan menggunakan prosedur yang sistematis dan ilmiah. Rumusan masalah penelitian hanya dapat dijawab berdasarkan temuan-temuan data empiris dari hasil penelitian. Metode penelitian adalah strategi umum yang ada dalam pengumpulan 
data dan analisis yang diperlukan guna menjawab persoalan yang dihadapi dan rencana pemecahan bagi persoalan yang sedang diselidiki (Moleong, 2007). Dalam penelitian ini peneliiti menggunakan beberapa metode, hal ini dimaksudkan agar mendapat hasil yang akurat dalam penelitian.

Dalam penelitian ini, peneliti menggunakan penelitian kualitatif deskriptif. Penelitian kualitatif deskriptif adalah suatu fenomena penelitian yang bertujuan untuk menggambarkan keadaan-keadaan atau status fenomena sesuatu yang terjadi yang terdapat dalam arti, baik dari kata-kata tertulis maupun lisan dari orang-orang yang menjadi subjek penelitian. Data yang dikumpulkan adalah berupa kata-kata atau gambar dan bukan angka- angka. Data tersebut mungkin berasal dari naskah, wawancara, catatan lapangan, foto, video tape, dokumen pribadi, catatan atau memo, dan dokumen resmi lainnya (Moleong, 2007). Dan penelitian ini termasuk dalam metode deskriptif dengan menggunakan pendekatan survey sejenis school survey. Metode deskriptif adalah suatu metode dalam meneliti status kelompok manusia, serta kondisi suatu sistem pemikiran ataupun suatu kelas tertentu tentang suatu peristiwa yang terjadi pada masa sekarang (Nazir, 2011).

Penelitian kualitatif berusaha menampilkan secara holistic yang membutuhkan kecermatan dalam pengamatan sehingga kita dapat memahami secara menyeluruh hasil penelitian, di samping itu dalam penelitian kualitatif ini peneliti harus terjun langsung ke lapangan guna memperoleh data yang peneliti butuhkan. Peneliti ini berusaha untuk menggambarkan dan mengklasifikasikan fakta atau karakteristik fenomena yang ada secara factual dan cermat, tidak mengandalkan bukti logika sistematis, prinsip angka atau metode stastik sehingga dapat digambarkan kondisi dan keadaan yang sebenar-benarnya dengan isyarat atau tindakan sosial.

Untuk menentukan data yang diperlukan, maka perlu adanya teknik pengumpulan data, agar bukti-bukti dan fakta yang diperoleh sebagai data yang obyektif, valid serta tidak ada penyimpanganpenyimpangan dari keadaan yang sebenarnya. Dalam mengumpulkan data, peneliti menggunakan teknik sebagai berikut 1) metode observasi; 2) metode dokumentasi; 3) wawancara (Subana, M. dan Sudrajat, 2001). Analisa data merupakan upaya untuk menelaah atau sistematika yang diperoleh dari berbagai sumber, yaitu wawancara, observasi, dokumentasi. Kemudian data tersebut diklasifikasikan sesuai dengan kerangka penelitian kualitatif deskriptif yang berupaya menggambarkan kondisi, latar penelitian secara menyeluruh dan secara data tersebut ditarik suatu temuan penelitian.

Dalam penelitian ini peneliti memberikan gambaran secara menyeluruh (holistic) tentang penilaian autentik mata pelajaran Pendidikan Agama Islam dan Budi Pekerti di SMP Negeri 4 Pariaman. Adapun gambaran hasil penelitian tersebut kemudian di telaah, 
dikaji dan disimpulkan sesuai dengan tujuan dan kegunaan penelitian. Dalam memperoleh kecermatan, ketelitian dan kebenaran, maka peneliti menggunakan pendekatan induktif.

\section{HASIL PENELITIAN DAN PEMBAHASAN}

Dalam mengimplementasikan penilaian autentik kurikulum 2013 dalam mata pelajaran pendidikan agama Islam dan budi pekerti tidak jauh berbeda dengan mata pelajaran yang lainnya. Dalam setiap mata pelajaran penilaian autentik lebih mengarah pada penilaian sikap, pengetahuan, dan keterampilan.

Dalam penilaian sikap ada empat poin yang dinilai, yaitu: observasi, percaya diri, teman, dan jurnal guru. Dari empat poin tersebut memiliki proses penilaian tersendiri. Sedangkan dalam penilaian pengetahuan ada empat poin yang dinilai, yaitu: ulangan harian, tugas, ulangan tengah semester, dan ulangan akhir semerter. Dalam penilaian keterampilan ada tiga poin yang harus dinilai, yaitu praktik, portofolio, dan project. Semua penilaian dan poin-poin penilaian di atas masuk dalam hasil belajar peserta didik. Sehingga dalam laporan hasil akhir angkaangka penilaian dan deskripsi penilaian menjadi penting untuk meningkatkan prestasi belajar peserta didik.

Dalam wawancara mengenai implementasi penilaian autentik kurikulum 2013 yang menjadi responden adalah wali kelas VII serta guru Pendidikan Agama Islam dan Budi Pekerti di SMP Negeri 4 Pariaman yaitu Ibu Siti Nur Inayah. S.Pd.I. Karena beliaulah yang lebih memahami tentang kurikulum 2013 serta penilaian autentik dalam kurikulum tersebut, sebagaimana yang telah di tetapkan bahwasanya kelas VII menjadi jenjang pertama dalam mengimplementasikan kurikulum 2013 (Wawancara, 13 Nov 2015).

SMP Negeri 4 Pariaman adalah salah satu lembaga pendidikan yang menjadi sekolah percontohan dalam mengimplementasikan kurikulum 2013. Menurut beliau, implementasi kurikulum 2013 serta penilaian autentik yang ada di dalamnya sangat tepat dalam proses belajar mengajar, karena peserta didik lebih ditekankan aktif dalam proses pembelajaran dengan menggunakan model pembelajaran scientific. $80 \%$ peserta didik yang lebih aktif dalam pembelajaran selebihnya guru hanya sebagai moderator.

Dalam pelaksanaan penilaian autentik kurikulum 2013 para guru dibuat lebih aktif karena kurikulum 2013 serta penilaiannya berbeda dengan kurikulum KTSP. Di mana dalam penilaian autentik kurikulum 2013 mengarah pada sikap, pengetahuan, dan keterampilan. Penilaian tersebut lebih ditekankan dalam keaktifan peserta didik untuk lebih aktif dalam proses pembelajaran, karena pada setiap langkah dan perbuatan peserta didik akan menjadi portofolio sendiri dalam penilaian guru, menjadikan para peserta didik lebih hati-hati dalam proses pembelajaran. 
Dalam implementasinya proses penilaian autentik sedikit rumit dikarenakan semuanya memakai data online dalam implementasinya, serta kurangnya pelatihan, workshop, dan informasi tentang penilaian autentik kurikulum 2013. Deskripsi penjelasan setiap model penilaiannya menjadi peran penting dalam penilaian autentik, guru juga kesulitan dalam penilaian portofolio di mana semua peserta didik dinilai dalam waktu yang bersamaan dengan waktu jam pelajaran yang begitu singkat atau dinamakan kelas gemuk (Wawancara, 13 Nov 2015). Lambat laun penilaian autentik menjadi terbiasa oleh guru karena sudah berjalan 1 tahun, sehingga memudahkan para guru menilai peserta didik sesuai peran aktif, sikap dan pengetahuannya, baik di dalam kelas maupun di luar kelas.

Dengan demikian, peserta didik tidak akan jenuh dalam proses pembelajaran, dikarenakan penilaian autentik menggunakan model pembelajaran scientific. Peserta didik lebih aktif dan kreatif dalam proses pembelajaran sehingga pada akhirnya bisa dilihat dari sikap serta hasil belajar peserta didik yang lebih baik.

Dalam implementasinya penilaian autentik kurikulum 2013 lebih menekankan pada tiga kompetensi, yaitu kompetensi sikap, kompetensi pengetahuan, dan kompetensi keterampilan. Pada kompetensi sikap penilaiannya melalui observasi, penilaian diri, penilaian antar peserta didik (peer evaluation), jurnal dan wawancara. Kelima teknik penilaian tersebut berjalan dengan baik dalam implementasinya, karena didukung dengan peran aktif serta perilaku para peserta didik dan pendidik baik dalam kelas maupun di luar kelas.

Penilaian kompetensi pengetahuan melalui tes tulis, tes lisan, dan penugasan. Ketiga teknik penilaian tersebut berjalan dengan sangat baik, karena dengan teknik penilaian tersebut pendidik dapat mengetahui kemampuan serta kecerdasan para peserta didik dalam mencermati dan memahami mata pelajaran yang telah diajarkan oleh pendidik.

Pendidik menilai kompetensi keterampilan melalui penilaian unjuk kerja, penilaian bentuk proyek, penilaian bentuk portofolio, dan penilaian bentuk produk. Keempat penilaian tersebut berjalan dengan baik, karena dalam implentasinya para peserta didik lebik aktif dan kreatif dalam mengembangkan tugas-tugas yang diberikan oleh pendidik, baik tugas dalam kelas maupun tugas yang dikerjakan di rumah.

Dengan penyajian data di atas, antara teori penilaian autentik kurikulum 2013 dengan implementasi penilaian autentik kurikulum 2013 sudah berjalan dengan baik meskipun kedepannya diperlukan inovasi agar lebih sempurna. Banyak faktor yang mendukung implementasi kurikulum 2013 baik yang bersangkutan dengan pendidik maupun yang bersangkutan dengan peserta didik. Sedangkan faktor penghambatnya kurangnya pelatihan dan workshop yang dilakukan oleh departemen pendidikan nasional. 


\section{KESIMPULAN}

Kesimpulan dalam penelitian ini adalah sebagai berikut 1) dalam implementasi penilaian autentik kurikulum 2013 di SMP Negeri 4 Pariaman sudah sesuai dengan apa yang ada di dalam buku panduan kurikulum 2013, meski ada tambahan inovasi dalam mengimplementasikannya. Proses penilian autentik di SMP Negeri 4 Pariaman memuat tiga model penilaian kompetensi, yaitu kompetensi sikap, kompetensi pengetahuan, dan kompetensi keterampilan. Pada kompetensi sikap, ada lima aspek yang dinilai yaitu kemampuan menerima, kemampuan merespons, kemampuan menilai, kemampuan mengatur atau mengorganisasikan, dan kemampuan berkarakter. Dari kelima kemampuan tersebut menggunakan lima teknik penilaian, yaitu observasi, penilaian diri, penilaian antar peserta didik, jurnal, dan wawancara. Dalam penilaian kompetensi pengetahuan ada enam aspek yang dinilai yaitu pengetahuan hafalan, pemahaman, penerapan, analisis, sintesis, dan evaluasi dengan menggunakan teknik penilaian tes tulis, tes lisan, dan penugasan. Ada enam macam tes tulis, antara lain soal pilihan ganda, isian, jawaban singkat, benar-salah, menjodohkan, dan uraian.

Dalam kompetensi keterampilan ada lima aspek yang dinilai, yaitu imitasi, manipulasi, presisi, artikulasi, dan naturalisasi dengan menggunakan empat teknik penilaian, antara lain penilaian unjuk kerja, penilaian bentuk proyek, penilaian bentuk portofolio, dan penilaian bentuk produk. Kemudian 2) faktor pendukung terimplementasinya penilaian autentik kurikulum 2013 di antaranya peserta didik lebih berperan aktif dalam proses pembelajaran, sekolah mengadakan pelatihan dan workshop dalam meningkatkan kualitas para pendidik dalam memahami implementasi kurikulum 2013 dan penilaian autentik, dan menyediakan sarana prasarananya. Sedangkan faktor penghambatnya antara lain kelas gemuk atau bisa diartikan pendidik tidak bisa menilai para peserta didik satu persatu dikarenakan jam pelajaran yang kurang panjang.

\section{KEPUSTAKAAN ACUAN}

Forum Mangunwijaya VII. (2013). Menyambut Kurikulum 2013. Jakarta: PT. Kompas Media Nusantara.

Hamalik, Oemar. (2010). Manajemen Pengembangan Kurikulum. Bandung: PT. Remaja Rosdakarya.

Kunandar. (2013). Penilaian Autentik (Penilaian Hasil Belajar Peserta Didik Berdasarkan Kurikulum 2013). Bandung: PT. Remaja Rosdakarya.

Moleong, Lexy J. (2007). Metodologi Penelitian Kualitatif. Bandung: Remaja Rodakarya.

Mulyasa, E. (2013). Pengembangan dan Implementasi Kurikulum 2013. Bandung: PT. Remaja Rosdakarya. 
Muzamiroh, Latifatul Mida. (2013). Kupas Tuntas Kurikulum 2013 Kelebihan dan Kelemahan Kurikulum 2013. Jakarta: Kata Pena.

Nata, Abuddin. (2012). Manajemen

Pendidikan Mengatasi Kelemahan

Pendidikan Islam di Indonesia. Jakarta:

Kencana Prenada Media Group.

Nazir, Mohammad. (2011). Metode Penelitian. Bogor: Ghalia Indonesia.

Poerwati, Endah Loeloek dan Amri, Sofan. (2013). Panduan Memahami Kurikulum 2013. Jakarta: PT. Prestasi Pustakarya.

Ramayulis. (2004). Ilmu Pendidikan Islam. Jakarta: Kalam Mulia.
Subana, M. dan Sudrajat. (2001). DasarDasar Penelitian Ilmiah. Bandung: Pustaka Setia.

Suharto, Toto. (2011). Filsafat Pendidikan Islam. Yogyakarta: Ar-Ruzz Media.

Sukmadinata, Syaodih Nana. (2011). Pengembangan Kurikulum Teori dan Praktek. Bandung: PT. Remaja Rosdakarya.

Undang-Undang No. 20 Tahun 2003

Zuriah, Nuzul. (2008). Pendidikan Moral dan Budi Pekerti dalam Perspektif Perubahan, Jakarta: Bumi Aksara. 